ANDRZEJ PIECZEWSKI

https://orcid.org/0000-0002-0643-1157

University of Lodz

\title{
ECONOMIC ARGUMENTS IN THE POLISH THOUGHT ON PEACE. JOHN BLOCH'S VIEWS AGAINST THE BACKGROUND OF THE POLISH THOUGHT ON PEACE
}

Zarys treści: Historia polskiej myśl irenologicznej sięga średniowiecza. Autor przedstawia, w syntetycznej formie i w porządku chronologicznym, koncepcje pokoju do początku XX w. Argumenty ekonomiczne zawsze towarzyszyły polskim koncepcjom pokoju. Ich siła różniła się w zależności od ogólnych trendów społecznych i intelektualnych w poszczególnych epokach. Jednak do czasu publikacji Przysztej wojny Jana Blocha (1836-1902) argumenty ekonomiczne nigdy nie stanowiły głównej argumentacji na rzecz pokoju. Niniejszy artykuł stanowi próbę ukazania oryginalności i znaczenia myśli Blocha - twórcy nowoczesnej koncepcji pokoju, opartej ściśle na argumentach ekonomicznych.

The content outline: The history of the Polish irenological thought goes back to the Middle Ages. The author presents, in a synthetic form and chronological order, concepts of peace developed before the beginning of the twentieth century. Economic arguments have always accompanied the Polish concept of peace. Their strength varied depending on the general social and intellectual trends prevailing in particular epochs. However, until the publication of The Future of War by John Bloch (1836-1902), economic arguments were never the main arguments for peace. This article is an attempt to show the originality and meaning of the thought of John Bloch - the creator of the concept of peace based strictly on economic arguments.

Słowa kluczowe: polska myśl o pokoju, argumenty ekonomiczne, Jan Bloch

Keywords: Polish thought on peace, economic arguments, John Bloch

Ideas of peace created at different times have always been closely associated with specific historical conditions. They have also included pan-historical, universal, humanistic values, and appealed to religious, political, and economic arguments. 
Similarly to the world's ideas, the Polish thoughts on peace represented and emphasized different topics, depending on historical conditions. ${ }^{1}$ One of the representatives of the Polish thought on peace was John Bloch (1836-1902), who created the concept of peace based on economic arguments. The aim of this study is to assess the originality and significance of Bloch's thought in this regard. I therefore present, in a synthetic form and chronological order, the arguments and concepts of peace of Polish authors (until the late nineteenth/early twentieth century). Economic motives, while undoubtedly constituting the most common cause of conflicts throughout history, did not appear frequently among the arguments in favor of peace. John Bloch's concept of peace and his arguments are presented against the historical background of the Polish thought on peace. This comparison will allow for assessing the place and importance of Bloch's thought in Polish irenology.

\section{Polish thought on peace in the Renaissance}

The researchers suggest the thirteenth century as the period of the birth of the Polish thought on peace. ${ }^{2}$ Although at that time Poland did not have separate academic centers, many Poles studied at universities in Western Europe, later bringing new ideas into Poland.

An interesting concept of "just and unjust wars" was presented by Marcin Bodula. ${ }^{3}$ It emerged against the background of the expansion of the Order of the Teutonic Knights, which Bodula condemned as incompatible with Christian doctrine and morals. He demonstrated that all wars of conquest carried out in order to gain wealth and/ or conquer new territories and peoples are unjust. War can be considered as just only in cases when it is carried out in order to tame aggressors, defend one's own land and wealth, or help others who are abused and enslaved. ${ }^{4}$

Considerable advancements in the Polish thought on peace can be found in the work of the so-called 'Cracow school of law of nations,'

${ }^{1}$ For studies related to the Polish thought on peace, see: R. Rosa, L. Wyszczelski, Wojna i pokój w polskiej myśli społecznej i wojskowej, Warszawa, 1996; R. Rosa, Filozofia bezpieczeństwa, Warszawa, 1995; Z. Kuderowicz, Polska filozofia pokoju. Historia idei pokoju w kulturze polskiej do 1939 roku, Warszawa, 1992.

${ }^{2}$ R. Rosa, L. Wyszczelski, op. cit., p. 7; W. Tatarkiewicz, Historia filozofii, vol. 1, Warszawa, 2001, pp. 309-313.

${ }^{3}$ Marcin Bodula - Archbishop of Gniezno (d. 1279).

${ }^{4}$ R. Rosa, L. Wyszczelski, op. cit., pp. 7-8. 
whose activity was closely associated with the political situation caused by the expansion of the Teutonic Order. ${ }^{5}$

The first rector of the renewed Academy of Cracow - Stanisław of Skarbimierz (year of birth unknown - died 1431) - was the author of many speeches arguing for peace. In his most famous De Bellis justus (On just wars) sermon, he proclaimed that wars based on motives of greed and hatred are against the laws of nature and as a result cause more harm than good. He tolerated the conduct of so-called 'just wars,' aimed at restoring peace between nations, recovering lost property and freedom, and defending the homeland. He valued peace higher than war, associating the former with justice. He demonstrated that peace and justice are consistent with the laws of nature, because they are conducive to the preservation and development of all forms of life (nature and human society). ${ }^{6} \mathrm{He}$ also disputed those pacifist views which questioned the admissibility of any war, even a just one, based on the argument that they always spread death, destruction, and suffering. Stanisław argued that while war's inherent misdeeds and killings are unavoidable in a just war, they are nevertheless acceptable, since they lead to the restoration of peace and justice and mitigate the much worse threat posed by an unjust war. The theoretical validity of the views of Stanisław of Skarbimierz expresses itself in his distinguishing between a just war and an unjust war. He declared that wars aimed at robbery or the destruction or restriction of the property and territory of a people were unacceptable, regardless of whether they were waged by Christian or pagan states. ${ }^{7}$

The thought of Stanisław of Skarbimierz was continued by Paweł Włodkowic of Brudzewo (b. 1370 - d. ca. 1435). He gained recognition by appearing at the Council of Constance as chairman of the Polish delegation to the Pope in the dispute with the Order of the Teutonic Knights. His most famous political and philosophical treatises are On the Authority of the Pope and the Emperor Against the Infidels and The Order of the

\footnotetext{
${ }^{5}$ At the beginning of the fifteenth century the Polish Kingdom was challenged by the Order of the Teutonic Knights, which questioned the authenticity of the baptism of Lithuania. The christianization of Lithuania deprived the Order of the moral right to conquer the Lithuanian lands and in this way constrained the Teutonic Knights in their territorial conquests. Poland found itself in a dispute with the Order because of its alliance with Lithuania, so it started a defensive war against the Order. The conflict was dealt with by the Council of Constance (1414-1415), where the Polish monarch sent a special delegation composed of scholars from Cracow, chaired by Paweł Włodkowic - Rector of the Academy of Cracow.

${ }^{6}$ L. Ehrlich, Polski wyktad prawa wojny XV wieku, Warszawa, 1955, pp. 115, 129.

${ }^{7}$ Z. Kuderowicz, op. cit., pp. 15-17.
} 
Teutonic Knights and the War of the Poles against Those Same Brothers. He included in these works the very original and, at that time, daring principle of religious tolerance in the law of nations and international relations. He emphasized the equality of Christian and pagan states and the right of every people to use their own territory and defend it. He was a firm opponent of aggressive and unjust wars, which he deemed morally unacceptable. He advocated the humanistic principle that faith can only be spread by the word, not the sword. He pointed out that pagan states, so long as they do not attack Christians, have the right to peaceful development. Moreover, he allowed for the possibility of an alliance between Christians and non-Christians in waging a just war against a common enemy. ${ }^{8}$ One can see in this a broader view of international relations, which for Włodkowic comprised not only religious communities but the entire international community. Based on his principle of unjust aggressive wars, Włodkowic also postulated the duty to return the property and territory seized in an unjust war. The restitution of plundered property was to provide moral and material satisfaction for those wronged. At the same time, he allowed the states conducting just wars to appropriate the gains obtained from an aggressor. ${ }^{9}$

The Polish irenological thought formulated in the fifteenth century ${ }^{10}$ was continued and sustained at the University of Cracow throughout the next century, as evidenced by the work of Andrzej Frycz Modrzewski and Sebastian Petrycy of Pilsen.

A.F. Modrzewski (1505-1572) belonged to the circle of intellectuals gathered around the court of King Sigismund Augustus and took an active part in the discussions on reforms aimed at ensuring the successful development of Poland. In his main work - On the Improvement of the Commonwealth - he indicated that a prerequisite for the success of a proposed series of reforms in the country (in law, education, economy, and army) was a successful solution to the issue of war and peace. Modrzewski listed a number of negative consequences of war, such as

${ }^{8}$ R. Rosa, L. Wyszczelski, op. cit., p. 9.

9 Z. Kuderowicz, op. cit., p. 19.

10 Stanisław of Dabrowka was one of the members of the Cracow Academy representing the 'Cracow school of law of nations.' He was also the author of the Treaty on the Newly Established Rulers, in which he argued that war should only serve as a means to consolidate peace, and only then can it be considered as just, because we do not conduct the war for the very sake of conducting the war, but in order to enjoy the peace; J. Domański, W. Tatarkiewicz, Filozofia i myśl spoteczna XIII-XV wieku, Warszawa, 1978, p. 286. 
a reduction in the number of people, material losses, and demoralization of both the army and the population living in areas where military operations take place. He emphasized the special role of peace as a guarantor of prosperity and happiness for both individuals and entire nations. Like many others, he professed the principle of tolerance in international relations and distinguished between just and unjust wars. He utterly condemned unjust wars, but allowed for just wars under certain conditions. He claimed that the most just cause for fighting a war was the need to defend oneself against an invading enemy. He associated effective defense with the internal reforms of the Commonwealth, including having its own strong and disciplined army consisting of "its own citizens." According to Modrzewski, the State was obliged to take care of a country's defense, which was to be effected by a good state of the economy, wise policy, fair social relations, and a strong army. ${ }^{11}$

Another representative of the Polish Renaissance, Sebastian Petrycy of Pilsen (1554-1626), was also involved in the deliberations on just and unjust wars, the equality of all states in international relations, and the issue of whether wars were in compliance or non-compliance with the laws of nature. In addition to these issues, he presented, in an essay, an interesting comparison of the benefits and losses of waging a war. This specific balance came out in favor of peace. Petrycy agreed with the thesis about the losses that war brings to both the victors and the vanquished, which included damages to material goods and to the size and health of the population, which he presented as disproportionately large in comparison to the unilateral territorial gains or the fame acquired in a war. ${ }^{12}$ In this way, Petrycy presented a view of the issues of war and peace from the standpoint of concern for the welfare of the whole society.

As noted by R. Rosa,${ }^{13}$ the views of Stanisław Orzechowski and Wawrzyniec Goślicki, who both referred to Aristotle, shared similar elements. Issues of war and peace, closely linked to the issue of security of the Commonwealth, also occupied the attention of many other humanists of this period: Andrzej Wolan, Łukasz Górnicki, and Krzysztof Warszawicki. The Polish Brethren (Arians) also shared an original view on these issues, but were divided into extreme and moderate pacifists (the latter allowing warfare under certain conditions).

\footnotetext{
${ }^{11}$ For more, see: A.F. Modrzewski, O poprawie Rzeczpospolitej, Warszawa, 1953.

${ }^{12}$ For more, see: S. Petrycy, Pisma wybrane, vol. 2, Warszawa, 1959.

${ }^{13}$ R. Rosa, L. Wyszczelski, op. cit., pp. 12-14.
} 


\section{Concepts created during the Enlightenment}

The nature and content of the Polish concepts of peace during the Enlightenment were mainly determined by the geopolitical conditions in which the Commonwealth found itself. Due to constant threats from its neighbors, Polish thoughts on peace were not developing in purely abstract categories, but in close connection with the question of defense of the country. Polish authors emphasized the economic, political, legal, moral, and military aspects of the issues of international peace. They believed that it was possible to reduce the occurrence of war through political and economic reforms, education, and upbringing.

An example of this view can be found in the writing ${ }^{14}$ of the Polish King Stanisław Leszczyński (1677-1766). He criticized visions of eternal peace, which in his opinion were unrealistic. Instead of projects full of utopian ideas based primarily on moral grounds, he believed it necessary to create an international order in which matters of peace would be based on more realistic factors. ${ }^{15}$ He recommended the establishment of a union of European states whose aim would be to eliminate wars. This was not, however, to be a federation, but permanent political and diplomatic activity through which various alliances would be concluded between sovereign rulers and an international 'just balance' would be obtained. Leszczyński predicted that the 'balance' would be supported by the so-called 'republican' states, i.e., those with representative forms of government such as England, the Netherlands, Poland, and Switzerland. According to Leszczyński, the cooperation of France, the main arbitrator in European disputes, was necessary to prevent endangering the peace. As noted by Z. Kuderowicz, the greatest originality of Leszczyński's thought lay in his accentuation of the political activity of countries interested in preserving the peace. ${ }^{16}$

Putting emphasis on historical context in regard to matters of peace was also characteristic of the Polish physiocrats. The Professor of Vilnius University Hieronim Stroynowski (1752-1815) viewed the law of nations as analogous to the rights of the individual, and those as analogous to the laws of nature. ${ }^{17}$ According to him, both the individual and the nation have the right to decide their own destiny. Therefore,

${ }^{14}$ S. Leszczyński, Głos wolny wolność ubezpieczajacy, Kraków, 1858.

15 J. Lechicka, Rola dziejowa Stanistawa Leszczyńskiego oraz wybór jego pism, Toruń, 1951.

${ }_{16}$ Z. Kuderowicz, op. cit., p. 63.

${ }^{17}$ H. Stroynowski, Nauka prawa przyrodzonego, politycznego, ekonomii politycznej i prawa narodów, Vilnius, 1785. 
he condemned all acts of subordination and the dependence of some states and nations on others. Given the interrelationships and common needs of people, while at the same time noting the diversity of countries as to their natural resources, he postulated the need for peaceful cooperation between them in the economic, political, and moral realm. This cooperation was to be the guarantor of security and development. Stroynowski wrote that: "A nation waging a war against another is firstly its own enemy [...] when it wastes public revenues on war [...] when it oppresses citizens with excessive tax burdens together with the diminution of annual reproduction and pure land income. Secondly, by losing people in the war it reduces the number of those working and consuming. Thirdly [...] it obstructs its external trade, and often even internal trade; the losses resulting therefrom [...] are obvious." ${ }^{18}$ R. Rosa observes that Stroynowski's theses resemble the then-current concept of positive peace: "If a war [...] brings only victims and damages (including waste of a large part of public income, population decline, barriers to trade), then peace [...] guarantees an unhindered exchange of material goods and spiritual values, thus contributing to the development of societies and states." ${ }^{19}$

Józef Kajetan Skrzetuski (1743-1806) sought to positively define the conditions for a guarantee of a lasting peace. He published a "Project or arrangement for uninterrupted peace in Europe" in which, referring to the idea of King Henry IV of France, he proposed the establishment of a federation of European state ${ }^{20}$ which would become the guarantor of peace. The federation was to be founded on international law respected by all countries. This law could not be breached by conquest, dictate, or political hegemony of one country. The federation would have to respect the sovereignty of all states and their equality before the law.

Skrzetuski also explained other benefits of the federation. He stressed that its establishment would prevent the conclusion of various alliances for predatory or invasive purposes, and would be conducive to consensus among nations. The existence of the federation would weaken the warlike ambitions of monarchs, and even cause changes in the hierarchy of values followed by governments. Instead of military successes, they would recognize the greater value of making the nation happy and securing its economic prosperity. In accordance with the economic doctrine of physiocratism, after the formation of the federation Skrzetuski

18 Ibid., p. 329.

${ }_{19}$ R. Rosa, L. Wyszczelski, op. cit., p. 20.

${ }^{20}$ K. Skrzetuski, Historia polityczna dla szlachetnej młodzi, Warszawa, 1775. 
expected agriculture to flourish and populations to grow, as well as for trade to be revived - which together constituted the main measures of the well-being of nations. ${ }^{21}$

Issues of war and peace became particularly important for the Poles during the threat to their independence and the incremental loss of territory resulting from the successive partitions. At that time, leading representatives of the reform camp, which was consolidated during the Four Years' Sejm (1788-1792) and passed the first Polish constitution, made further attempts to develop the theoretical and praxeological bases in the field of security. War began to be perceived as a social phenomenon which should be not only condemned, but also understood.

It was in this historical context that Hugo Kołłątaj (1750-1812) deliberated over the issues of peace and war. ${ }^{22}$ In his opinion, it was beyond doubt that international conflicts constantly appeared in the history of societies, and that as a result stronger states subordinated entire peoples, appropriated their possessions, and forced them into slave labor. He then posed the question: How is it possible that, despite the universality of the law of nature which excludes wars and conflicts, they have nevertheless become a permanent fixture of social life and international relations? In this way, he developed a series of psychological concepts in which he sought explanations for the causes of the occurrence of wars. According to Kołłątaj, the achievement of peace is a process requiring long-lasting social, economic, political, military, and educational changes, a process which can last for several generations. ${ }^{23}$

Like Kołłataj, Stanisław Staszic was also of the opinion ${ }^{24}$ that war appeared only at a certain stage of social development, as an expression of the selfish interests of individuals and groups aimed at seizing foreign territories, acquiring wealth, and enslaving others and forcing them to work for them. He considered wars implementing these objectives as contrary to the laws of nature and therefore unjust. He distinguished these wars from another kind of war - just wars which defend property and freedom, or restore freedom of persons and eliminate enslavement.

${ }^{21}$ Z. Kuderowicz, op. cit., pp. 75-76.

${ }^{22}$ H. Kołłątaj, Rozbiór krytyczny zasad historii o poczatkach rodu ludzkiego czyli racjonalistycznie podjęty wstep do historii, Warszawa, 1842; id., Porzadek fizyczno-moralny, czyli nauka o należytościach i powinnościach człowieka, wydobyty z praw wiecznych, nieodmiennych i koniecznych, Warszawa, 1810.

${ }_{23}$ Z. Kuderowicz, op. cit., pp. 78-84; R. Rosa, L. Wyszczelski, op. cit., pp. 23-25.

${ }^{24}$ S. Staszic, Pisma filozoficzno-społeczne, ed. B. Suchodolski, Warszawa, 1954. 
Staszic believed that in the future there would be a lasting peace - an indispensable condition for the security and happiness of people. $\mathrm{He}$ devoted much attention to the discussion of the path to achieve such a lasting peace. He suggested the formation of an "association of nations" which would voluntarily renounce violence in their mutual relations, an idea he supposed would be put forward by the Slavic peoples. In his deliberations one can also find a utopian image of the federation of peoples who communicate using a common language, create a common system of measurements, a common currency, and also profess one religion. He attributed a substantial role to economic factors, including the freedom of international trade, in the striving for federation.

\section{The era of Romanticism}

At the beginning of the nineteenth century, the issues of war and peace became enriched with new threads in Poland. Polish territory was under the authority of occupying powers. Due to its loss of independence, political content in Poland began to give way to cultural content. National feelings and sentiments were growing, which was also consistent with the pan-European trend at that time. National ties proved stronger and more durable than state institutions. The nation began to be understood as a cultural community bonded by common traditions, language, customs, literature, and art. In these new conditions, Polish thinkers, following the way paved by their predecessors, complemented existing ideas and concepts with new threads characteristic of the Romantic period. The concept of the nation and its right to selfdetermination and peaceful existence became the central focus. This perspective, along with many others, is reflected in the writings of such authors as Adam Jerzy Czartoryski25 (1770-1861), Józef Maria Hoene-Wroński26 (1776-1853), Wojciech Bogumił Jastrzebowski ${ }^{27}$ (1799-1882),

${ }^{25}$ A. Czartoryski, Essai sur la Diplomatie, Paris, 1864, $2^{\text {nd }}$ ed.; For contemporary translation into Polish with study by M. Kornat see: A. Czartoryski, Rozważania o dyplomacji, transl. J.M. Kłoczowski, study: M. Kornat, Reforma dyplomacji i legitymizm narodów, Kraków, 2011; A. Czartoryski, Pamiętniki i memoriały polityczne 1776-1809, ed. J. Skowronek, Warszawa, 1986.

${ }_{26}$ J.M. Hoene-Wroński, Metapolityka, transl. J. Janowski, Warszawa, 1923.

27 W.B. Jastrzębowski, Traktat o wiecznym przymierzu między narodami ucywilizowanymi. Konstytucja dla Europy, ed. and foreword by F. Ramotowska, Warszawa-Łódź, 1985; The manuscript is stored in AGAD [The Central Archives of Historical Records] in Warsaw. For the digital version of the manuscript, see: Wojciech Bogumit 
[Father] Piotr Ściegienny ${ }^{28}$ (1800-1890), Karol Libelt ${ }^{29}$ (1807-1875), Bronisław Trentowski ${ }^{30}$ (1808-1869), August Cieszkowski ${ }^{31}$ (1814-1894), Adam Mickiewicz (1798-1855), and Zygmunt Krasiński (1812-1859).

Polish Romantic thought ${ }^{32}$ strongly accentuated the principle of national pluralism, according to which all peoples (nations) are equal and have the right to independent development. A nation does not die following the loss of its independence, and its striving to regain its sovereignty is morally justified. Despite peace being the most important value, in this case a war for national liberation is justified. What is more, lack of sovereignty and national oppression were treated as a permanent threat to universal peace. The Polish Romantic thought also developed a number of practical recommendations on how to regain and maintain independence. It was postulated that the national liberation struggle of one country should be interlinked with the same struggle of other nations. One should also note here the forceful proposal to create a federation of free and sovereign nations as a guarantor of peace. These ideas are also associated with the postulate that diplomacy and international politics should be moralized and based on Christian principles. Another valuable contribution of Romantic thought was the emphasis put on the idea of educating societies in the spirit of peace. However, it should be noted that the creators of the Romantic current, in accordance with the ideological assumptions of the time, devoted little or no attention to the economic arguments in favor of peace.

\section{Positivism and the thought of John Bloch}

The issues of war and peace were also deliberated upon in the period of Positivism, an era characterized by philosophical foundations quite opposite to Romanticism. The search for peace went in other, more rational directions and the reasoning gravitated toward political and economic issues.

\footnotetext{
Jastrzębowski (1799-1882), ed. M. Morawska, Warszawa, 2011, http://agad.gov.pl/ wp-content/uploads/2016/06/jastrzebowski-internet_1.pdf (1 XI 2019).

${ }^{28}$ C. Wycech, Ksiadz Piotr Ściegienny. Zarys programu społecznego i wybór pism, Warszawa, 1953.

${ }^{29}$ K. Libelt, Karola Libelta rozprawy o odwadze cywilnej, miłości ojczyzny, wychowaniu ludów, Kraków, 1869.

${ }^{30}$ B. Trentowski, Stosunek filozofii do cybernetyki, Warszawa, 1974.

31 A. Cieszkowski, Prolegomena zur Historiosophie, Berlin, 1838.

${ }^{32}$ R. Rosa, L. Wyszczelski, op. cit., pp. 30-37.
} 
The early views of Henryk Kamieński (1813-1865) can be classified as belonging to the previous Romantic era. ${ }^{33}$ However, following his return from exile, he wrote a comprehensive, erudite work entitled Russia and Europe. Poland, published in Paris in 1857. In this work, he sought, based on historical analysis and sociological inquiries, to determine the political situation in Europe and indicate its main determinants. As noted by Z. Kuderowicz, ${ }^{34}$ Kamieński's work injected new aspects into the issues of war and peace, because he treated the issue of the possibility of war (or peace) as a consequence of the balance of power in Europe. He no longer believed that peace was dependent on moralizing international politics. He came to the conclusion that relations between states are governed by their aspirations and by their pursuit of their own benefits, and that these are the only real forces that must be taken into account. His departure from moralizing was an important sign of rejection of the Romantic philosophy of peace. Kamieński proceeded to analyze war and peace as a result of clashes of different political tendencies represented by various sovereign states. His methodological attitude can be called that of a political scientist. We can also deem him a precursor of the deliberations on geopolitical aspects of peace in the Polish literature.

John Gottlib Bloch (1836-1902) was another representative of Positivist thought - an industrialist, financier, and Polish railroad magnate who built railroads in Russia and in territories under Russian occupation. ${ }^{35}$ He presented his considerations in several studies, the culmination of which was his multi-volume work The Future of War in Its Technical, Economic and Political Relations ${ }^{36}$ (1 ${ }^{\text {st }}$ Ed. 1898).

${ }^{33}$ Henryk Kamieński published, under the pseudonym of Filaret Prawdowski, two brochures - O prawdach żywotnych narodu polskiego (1844); and Katechizm demokratyczny czyli opowiadanie stowa ludowego (1845) - in which he promoted the view that lasting peace can only take place after the so-called "Final war" in which peoples will rebel against despotic governments and defeat them.

${ }^{34}$ Z. Kuderowicz, op. cit., p. 149.

35 See more on Bloch: R. Kołodziejczyk, Jan Bloch (1836-1902). Szkic do portretu “króla polskich kolei,” Warszawa, 1983; A. Bocheński, Wędrówki po dziejach przemystu polskiego, vol. 2, part 2, Warszawa, 1969; id., Niezwykte dzieje przemystu polskiego, Warszawa, 1985; A. Żor, Figle Historii, Torun, 2005; Jan Bloch (1836-1902). Kapitalista, pacyfista, filantrop, ed. A. Żor, Warszawa, 2014.

${ }^{36}$ J. Bloch, Przyszła wojna pod względem technicznym, ekonomicznym i politycznym, vol. 1-5, Warszawa-Kraków, 1900. Also published in Polish, Russian, French, German, English, and Dutch. English edition: The Future of War in Its Technical, Economic and Political Relations by Jean de Bloch, Boston: Ginn \& Company, 1903. The book was digitized by the Internet Archive in 2007 with funding from the Microsoft Corporation: http://www.archive.org/details/futureofwarinits00blociala. 
The international situation and the growing tension at the end of the nineteenth century - related to intensified preparations for a European military conflict - led him to undertake research on this topic. ${ }^{37}$

The Future of War in Its Technical, Economic and Political Relations is a thorough and in-depth analysis of total armed conflict conducted on three levels: 1) The technical means of destruction and the effects of their use, including the faces of the new armies and scenarios of the new battlefields, created on the basis of the achievements of the Industrial Revolution; 2) Economic needs of the military and the demographic and economic consequences of world war, both for individual countries and Europe as a whole; and 3) Potential political and social upheavals occurring during and after the conflict.

According to Bloch, the future total war would radically diverge from all previous conflicts known to mankind. First of all, it would be different in terms of the incomparably greater human and material potential involved. It would contain the seeds for unprecedented destruction and loss of life, due to the application of combat measures offering tremendous capabilities for destruction. Bloch also listed a whole series of economic consequences of this total conflict. These included: material war losses and damages, huge war debts, the collapse of the budgets of struggling countries, inflation on a massive scale, the collapse of banking systems and the gold standard, and the underfunding of industry, which in turn would result in a drastic decline in the living standards of the populations. It was foreseen that the economic chaos would be accompanied by growing political instability and social destabilization in the form of strikes, rebellions, and even riots, which could in turn escalate into - what was feared the most - a socialist revolution.

The analysis presented by Bloch is of scientific nature, as are the partial conclusions presented in the work. However, the substance and the message of the work have ideological (pacifist) overtones, and they are surprisingly simple - that war in its contemporary form does not make sense. There will be no victors and no vanquished, because the effort exerted in war will exhaust all the warring countries in terms of their economies and destabilize them politically and socially. As was noted by Grzegorz Babiak, ${ }^{38}$ in his reflections Bloch argued that the

${ }^{37}$ In 1893, France and Russia formed an alliance. Relations between Germany and Austria were tightening and at the same time the tension in Russian-Austrian relations was growing.

${ }^{38}$ G. Babiak, "Jan Gottlieb Bloch (1836-1902). Portret zapomnianego pacyfisty," in: J.G. Bloch, Przyszła wojna pod względem technicznym, ekonomicznym i politycznym, Warszawa, 2005, p. 7. 
outbreak of war was improbable. Hence his work was a kind of conjuring up of the statesmen in an attempt to produce a multilateral proof of the concept that, from the point of view of political logic, such a future war could mean the destruction of humanity and therefore was totally irrational and should not be possible.

In a series of articles he wrote: "In truth, a war sparked by Germany would be tantamount to suicide. It would deprive millions of people of their daily piece of bread, so the normal collection of taxes to meet budgetary needs would be out of the question. Meanwhile, an army of a million, which Germany would need to draw up, would take more than 20 million marks a day for necessary expenses." ${ }^{39}$ He saw international treaties as the only way to amicably settle disputes. Preserving peace in Europe was also important, according to Bloch, because of the dangers associated with "[...] the competition of America, gaining with each passing day advantage in European markets, and also due to the interest of agriculture around the world." ${ }^{40}$ As noted by G. Babiak, in the The Future of War Bloch argued, moreover, that if the spontaneously growing American economy, possessively seeking new buyers, did not encounter strong resistance from a Europe weakened by war, it would oust Europe even from its own markets, causing economic damage beyond repair. ${ }^{41}$

It is very rare in social sciences that an author's prediction turns out to be extremely accurate. In this case, however, the precision of Bloch's forecasts at the general level is indeed impressive. World War I destabilized Europe. In Russia and Germany, the economic and social turmoil caused by the war produced the birth of two anti-humanist ideologies communism and Nazism. As is known, Nazism led to the cataclysm of World War II and communism fueled armed conflicts around the world for decades. And just as predicted by Bloch, as a result Europe passed the civilizational and economic torch to America.

Bloch expressed reluctance toward the moralistic attitudes concerning war and peace arising from religious and philosophical arguments. He was obviously aware of the rich tradition of moralizing pacifism in Europe; moreover, he believed that it played an important role in shaping social attitudes towards war and peace. However, Bloch was convinced that the issues surrounding the existing conflicts could not be resolved in the sphere of morals or beliefs. He claimed that matters

\footnotetext{
39 J. Bloch, "Finanse i wojna," Kurier Warszawski, 1901, no. 353, p. 3.

${ }^{40}$ Id., "Finanse i wojna," Kurier Warszawski, 1901, no. 346, p. 2.

${ }^{41}$ G. Babiak, op. cit., p. 14.
} 
of war and peace depended on the technical and economic conditions in which societies live, and their impact on politics. Bloch dealt with war, as well as the various forms of protest against the war, as civilizational phenomena which could be explained by the peculiarities of social development.

Bloch pointed out that alongside the development of civilization, war also involves an increasing number of people and entails a growing number of victims. He demonstrated, based on statistical material, the projected increase in economic losses, such as the destruction of property of the state and civilians, suppression of trade, and increased state spending for military purposes. He noted that the latter tendency was intensifying in modern times, which meant an increase in the tax burden on the population, at the expense of meeting their everyday needs.

A characteristic feature of Bloch's philosophy of peace was his belief that in the development of civilization two conflicting tendencies take place simultaneously. The first is the "militarism" derived from overpopulated countries which have problems with meeting the needs of their populations. Militarism, that is the pursuit of war, results from the state's function as the defender and guarantor of the safety of its residents. Bloch put it this way: 42 "The offerings of the nation for the maintenance and improvement of their armed forces are, according to the militarists, the necessary and natural consequence of the existence of states."

The second tendency is the opposite - anti-militarism - which, according to Bloch, is based on changes in the conditions of social life. This he explained as follows: "[...] the transformation of the living conditions and the changes made in the composition of the army have prepared the ground on which the reluctance of the masses toward war has been developed. Complicated economic conditions, the mutual connections between various branches of manufacturing, the advantage of economic interests and work over other factors in the modern state - all this puts people off from war, which is not only a terrible misfortune in the event of a defeat, but also the source of many difficulties and dramatic losses even in the case of the most brilliant victory. In the times when the army consisted of mercenaries, or professional officers and soldiers who spent their entire lives under arms, then war was indeed for these people a path to honor and wealth. In our times, however, it is

42 J. Bloch, Przyszła wojna pod względem technicznym, ekonomicznym i politycznym, vol. 5, Warszawa: Nakład Gebethnera i Wolffa; Kraków: Gebethner i Spółka, 1900, p. 133. 
the masses who are otherwise occupied with peaceful affairs and interests which are being conscripted. For them war is not only a personal danger, but also a source of property ruin and family misfortunes. No wonder that nowadays the perception of war among soldiers is completely different from what it used to be. All young people who are to perform military service simply oppose any war undertakings, and those who are already in service are eagerly awaiting the time when they are free to return to their proper activities, to work for themselves and their family: and they do not at all relish the near prospect of a war." ${ }^{43}$ According to Bloch, anti-militarism and the accompanying criticism of the war and aversion to military service were social phenomena, the size of which was expanding during Bloch's times.

As Marek Kornat stated, the eloquent manifesto The Future of War was an example of the latter approach, as it assumed the rationalization of international relations. Bloch appeared to believe in progress in this field. He also referred to a realistic imagination showing the tragic consequences of war in the industrial era. ${ }^{44}$

The Future of War brought Bloch international acclaim. In August 1898, the young Tsar Nicholas II took the initiative to convene an international peace conference in the Hague. He issued a manifesto against war in which he repeated word-for-word the arguments from the works of Bloch. ${ }^{45}$ The Hague Peace Conference was held between 18 May and 29 July 1899 on the outskirts of the Hague, in the Maison du Bois. It was attended by 26 countries, mainly from Europe, as well as the USA, Mexico, China, Japan, and Persia. The conference adopted several conventions and established the Permanent Court of Arbitration. The final act recommended states to consider the possibility of arms reduction. ${ }^{46}$ Bloch was not a member of any of the 26 official government delegations, but he took an active part in deliberations as an observer. ${ }^{47}$ Although the Hague Conference did not prevent the outbreak of what was then called the Great War, it was, however,

43 Ibid., p. 164.

${ }^{44}$ M. Kornat, "Liberalny internacjonalizm. Jan Bloch, Rosja i sprawy pokoju," in: Jan Bloch, pacyfizm europejski i wyobraźnia Wielkiej Wojny. Studia i rozważania, ed. M. Kornat, Warszawa, 2016, pp. 86-87.

${ }^{45}$ Jan Gottlieb Bloch (1836-1902). Szkic biograficzny, www.bloch.org.pl, 2008, p. 17.

${ }^{46}$ E. Osmańczyk, Encyklopedia ONZ $i$ stosunków międzynarodowych, Warszawa, 1982, p. 261.

${ }^{47}$ E. Małecka, "Konferencja Haska i Jan Bloch przeciwko wielkiej wojnie," Wojsko $i$ Wychowanie, 2000, no. 5, pp. 142-150. 
the first worldwide assembly of this type, and undoubtedly drew the attention of the international public opinion to issues of peace. Bloch commented on the Conference as follows: "The renunciation of the armaments madness cannot be avoided. But why does it happen only at the cost of unnecessary victims and undeserved misfortune? [...] But all is not lost yet. Propaganda in favor of a healthy mind and progress must eventually prevail. The results of the civilization work in the Hague we are sure - have been only somewhat delayed." 48

Bloch's original idea was to create the world's first Peace Museum in Lucerne. ${ }^{49}$ Its creation was aimed at showing what war was and why one should strive for world peace. Although the Museum did not survive World War I, it gave rise to other numerous establishments of this type which have emerged in the world. ${ }^{50}$

Bloch's activities for peace met with approval of the international public opinion. He was nominated for the Nobel Peace Prize ${ }^{51}$ by many institutions, including the Polish Academy of Learning. Unfortunately, this most likely winner of the prize died in 1902, before being granted the accolade. ${ }^{52}$

Despite his international acclaim, Bloch did not win the favor of his compatriots. ${ }^{53}$ His pacifist views were in conflict with the sentiment generally prevailing on the Polish soil, manifested in the conviction that only a general war would be able to return freedom to Poland, while Bloch saw a chance for the coexistence of nations in disarmament. The first step towards this idea was to make societies, and above all their elites, aware of the risks and threats posed by modern war.

Bloch was, ironically, best known in Western Europe as a Polish ideologue of peace, hailed by some as the "father of modern pacifism." Norman Angell (1872-1967) - author of The Great Illusion ${ }^{54}$ and one

${ }^{48}$ J. Bloch, "Niemcy i pokój zbrojny," Kraj, 1901, no. 46, pp. 2-3.

${ }^{49}$ P. van den Dungen, "Zapobiegając katastrofie: pierwsze na świecie Muzeum Pokoju," in: A Unique Memorial Book Dedicated to Professor Ikuro Anzai, Isaru, 2006, pp. 23-36.

50 Jan Gottlieb..., p. 18.

${ }^{51}$ P. van den Dungen, "Jan Bloch and the Inaugural Nobel Peace Prize (1901)," Det Norske Nobelinstitutts Skriftserie. The Norwegian Nobel Institute Series 3, 2002, no. 2, pp. 1-27.

${ }^{52}$ G. Babiak, op. cit., p. 13.

${ }^{53}$ On the causes of Bloch's 'repression' from collective consciousness see: A. Żor, "Wokół intelektualnej biografii Jana Blocha," in: Jan Bloch, pacyfizm europejski i wyobraźnia Wielkiej Wojny..., p. 15.

${ }^{54}$ For more, see: M. Ceadel, Living the Great Illusion: Sir Norman Angell, 1872-1967, Oxford, 2009; J.D. Bruce Miller, Norman Angell and the Futility of War, London, 1986. 
of the most famous twentieth-century Anglo-Saxon advocates for peace, knew Bloch's work well and highly appreciated The Future of War. He spoke of Bloch as follows: ${ }^{55}$ "I do not desire in the least, of course, to create the impression that I regard the truths here elaborated as my 'discovery,' as though no one had worked in this field before. Properly speaking, there is no such thing as priority in ideas. The interdependence of peoples was proclaimed by philosophers three thousand years ago. [...] This does not prevent, I trust, the very highest appreciation of earlier and better work done in the cause of peace generally. The work of Jean de Bloch, among others, though covering different ground from this, possesses an erudition and bulk of statistical evidence to which this can make no claim. [...]."

The comparison of the views of these two thinkers ${ }^{56}$ shows that Bloch wanted to scare the readers with consequences of the future war, while Angell wanted his audience to realize the fallacy of thinking that war brings wealth to the nation. As far as their analyses are concerned, Bloch devoted a lot of space to analyzing modern weapons. He also pointed to the influence of total war on economy and politics. Angell focused on the role of political and military power in economic prosperity. He also put emphasis on the changing human mentality. Bloch concluded that future war would look quite different from the previous ones. It would be longer and more expensive than any earlier conflict. He stressed the great losses and the economic and political turbulence, including a socialist revolution, which future war could induce. Angell concluded that in the present day, war would no longer bring the expected benefits. The role of physical force was diminishing in all spheres of human life. His message was that the aim should be to change the political and public opinion on the impact of war on economic prosperity. Bloch's message consisted in the claim that total war equaled destruction of humanity. From the logical point of view, total war should never break out.

Bloch's and Angell's views on peace are fairly similar. They differ only in the arguments used. First of all, they both revolve around firm, economic arguments in favor of peace. They both point to the rapid change of economic and social relations that stand in contrast with the

${ }^{55}$ N. Angell, The Great Illusion, New York and London, 1910, p. 406.

${ }^{56}$ For a more detailed comparison of Bloch's and Angell's views see: A. Pieczewski, "John Bloch's 'The Future of War.' Pacifism Based on Economics," Annales. Etyka w życiu gospodarczym 19, no. 4, pp. 75-77; Cf: D. Grzybek, "O nieracjonalności wojny - Jan Bloch w perspektywie porównawczej," in: Jan Bloch, pacyfizm europejski i wyobraźnia Wielkiej Wojny..., pp. 137-143. 
outdated views on war and peace which prevail among the elites and societies. Both authors were aware of the key task that stood before them: an attempt to change these views.

Among the group of thinkers who developed original concepts of war and peace one can also include Feliks Koneczny (1862-1949) - the creator of the theory of civilization who sought to discover the historical laws governing social development. ${ }^{57}$ Through his research on the processes of civilizational transformation, Koneczny came to the conclusion that the essential causes of wars lay in the so-called "ability of civilizations to expand," that is to acquire for themselves, in different ways, their followers. According to him, historical law holds that adjoining civilizations fight with each other, and the stronger eliminate or subordinate the weaker. Koneczny distinguished between various forms of civilizations' ability to expand: a) peaceful universalism, consisting in flexibility and openness of the given culture; b) intellectual universalism, promoting the ideas and beliefs relevant from the point of view of a particular civilization; c) state universalism, identified with militarism and aiming to achieve military advantage. As noted by R. Rosa, ${ }^{58}$ Koneczny criticized pacifist ideologies for spreading illusions about eternal and universal peace. He did, however, allow for the possibility of peace, but within one civilizational community.

The beginning of the twentieth century witnessed a multiplicity of concepts for regaining - and maintaining - of independence by Poland. There existed a number of currents, but the two major ones were the national trend and the socialist trend. During the interwar period, projects for the federal arrangement of relations in Europe and the world as a guarantor of peace became popular in Poland.

\section{Conclusions}

The above overview leads to the conclusion that Polish irenology is quite rich. It's chief characteristic is that it has always germinated and developed on the basis of the current situation in the country. Nonetheless, it also contained and reflected universal, pan-historic values.

During the Renaissance, the Polish thought was linked in many ways with European culture and philosophy and focused on the religious and moral aspects of war. This thread was dominant, and attempts were

\footnotetext{
57 F. Koneczny, Prawa dziejowe, London, 1982.

${ }^{58}$ R. Rosa, L. Wyszczelski, op. cit., p. 44.
} 
made to find the sources and the essence of war and peace, and to establish the distinction between just and unjust wars. Economic arguments were rare, but the great importance of peace for the development of the economy, trade, art and culture began to be noticed.

In the age of Enlightenment, also known as the era of rationalism, the issue of peace began to be based on more realistic factors rather than just on moral premises. Based on the so-called "laws of nature," it was proclaimed that peace was the natural state of humanity, while war was the "robbery of humanity, a quarrel of tyrants whose prey is the human race." ${ }^{9}$ The importance of peace was stressed as the highest value enabling the development and security of nations. Economic aspects played a very important role, especially in the considerations of Polish physiocrats. Economic cooperation between countries began to be perceived as a guarantee of security. All sorts of visions were devised for the arrangement of relations in Europe in order to ensure peace, which mainly revolved around some form of a federation in which economic cooperation would hold a prominent place.

Romanticism, more idealistic by its very nature, largely neglected the economic arguments in favor of peace. At that time, the religious, moral and political threads dominated the debate on war and peace, with appeals to Christianity and to Christ's commandment to love one's neighbor postulating the moralization of diplomacy and the education of populations in peace. The central issue involved the concept of a nation and its right to self-determination and peaceful existence. It was also pointed out that lack of sovereignty and national oppression poses a permanent threat to peace. There were plans for federations of free and sovereign nations as guarantors of peace. Economic elements were hardly present in the considerations of the representatives of this trend.

The era of Positivism brought about a reversal with respect to the weight of various arguments. Moralizing was abandoned in favor of purely political and economic issues. An attempt was made to explain the issues of war and peace as phenomena determined by social, political, and economic relations. It was asserted that relations between states are governed by their aspirations and strivings for their own benefit, and that these are the only real forces that need to be taken into account.

The causes of war were sought in conflicts of interest not only at the state level, but also between whole civilizations. Economic arguments began to play a prominent role. It was claimed that matters of war and peace depend on the technical and economic conditions in which

${ }^{59}$ Ibid., p. 26. 
societies live, and the impact of such conditions on politics. Attention was drawn not only to the rising costs of war itself, but also to the costs of preparations for war. The development of technology and the future total war were perceived as threats to the social, economic, and political stability of countries and nations.

Generally we can conclude that economic arguments have accompanied the Polish irenology from the beginning. Their strength has varied in relation to the general social and intellectual trends prevailing in successive epochs. They were more espoused during the period when rationalism dominated in intellectual currents, and subsequently marginalized when Romantic idealism was at the helm. However, until the publication of the views of John Bloch, economic arguments had never constituted the main argumentation in favor of peace. Bloch's conclusions were also based on a scientific analysis steeped in empiricism. He cited a great amount of statistical data to support his hypotheses, and abandoned moralizing in favor of hard economic argumentation and 'wishful thinking' in favor of scientific analysis. In this sense, he distinguished himself from all previous Polish thinkers. In fact, owing to his approach, Bloch's thought also stands out against the background of the international thought on peace.

\section{Bibliography}

Angell N., The Great Illusion, New York and London, 1910.

Bąbiak G., "Jan Gottlieb Bloch (1836-1902). Portret zapomnianego pacyfisty," in: J.G. Bloch, Przyszła wojna pod względem technicznym, ekonomicznym i politycznym, Warszawa, 2005, pp. 7-54.

Bloch J., "Finanse i wojna," Kurier Warszawski, 1901, no. 346.

Bloch J., "Finanse i wojna," Kurier Warszawski, 1901, no. 353.

Bloch J., The Future of War in Its Technical, Economic and Political Relations by Jean de Bloch, Boston, 1900 (the book was digitized by the Internet Archive in 2007 with funding from the Microsoft Corporation: http://www. archive.org/details/futureofwarinits00blociala).

Bloch J., "Niemcy i pokój zbrojny," Kraj, 1901, no. 46.

Bloch J., Przyszła wojna pod względem technicznym, ekonomicznym i politycznym, vol. 1-5, Warszawa, 1903 (also published in Russian, French, German, English, and Dutch).

Bocheński A., Niezwykte dzieje przemystu polskiego, Warszawa, 1985.

Bocheński A., Wędrówki po dziejach przemystu polskiego, vol. 2, part 2, Warszawa, 1969.

Cieszkowski A., Prolegomena zur Historiosophie, Berlin, 1838.

Czartoryski A., Essai sur la Diplomatie, Paris, 1864, $2^{\text {nd }}$ ed. 
Czartoryski A. Pamiętniki i memoriały polityczne 1776-1809, ed. J. Skowronek, Warszawa, 1986.

Czartoryski A., Rozważania o dyplomacji, transl. J.M. Kłoczowski, study: M. Kornat, Reforma dyplomacji i legitymizm narodów, Kraków, 2011.

Domański J., Tatarkiewicz W., Filozofia i myśl społeczna XIII-XV wieku, Warszawa, 1978.

Dungen P. van den, "Jan Bloch and the Inaugural Nobel Peace Prize (1901)," Det Norske Nobelinstitutts Skriftserie. The Norwegian Nobel Institute Series 3, 2002, no. 2, pp. 5-27.

Dungen P. van den, "Preventing Catastrophe: The World's First Peace Museum, "Ritsumeikan Kokusai Kenkyu" [The Ritsumeikan Journal of International Studies], 2006, No. 18 (3), pp. 23-36.

Ehrlich L., Polski wyktad prawa wojny XV wieku, Warszawa, 1955.

Grzybek D., "O nieracjonalności wojny - Jan Bloch w perspektywie porównawczej," in: Jan Bloch, pacyfizm europejski i wyobraźnia Wielkiej Wojny. Studia $i$ rozważania, ed. M. Kornat, Warszawa, 2016, pp. 119-150.

Hoene-Wroński J.M., Metapolityka, transl. J. Janowski, Warszawa, 1923.

Jan Bloch (1836-1902). Kapitalista, pacyfista, filantrop, ed. A. Żor, Warszawa, 2014.

Jan Bloch, pacyfizm europejski i wyobraźnia Wielkiej Wojny. Studia i rozwa$\dot{z}$ ania, ed. M. Kornat, Warszawa, 2016.

Jan Gottlieb Bloch (1836-1902). Szkic biograficzny, www.bloch.org.pl, 2008.

Jastrzębowski W.B., Traktat o wiecznym przymierzu między narodami ucywilizowanymi. Konstytucja dla Europy, ed. and foreword by F. Ramotowska, Warszawa-Łódź, 1985.

Kołłąaj H., Porzadek fizyczno-moralny, czyli nauka o należytościach i powinnościach człowieka, wydobyty $z$ praw wiecznych, nieodmiennych $i$ koniecznych, Warszawa, 1810.

Kołłątaj H., Rozbiór krytyczny zasad historii o początkach rodu ludzkiego czyli racjonalistycznie podjęty wstep do historii, Warszawa, 1842.

Kołodziejczyk R., Jan Bloch (1863-1902). Szkic do portretu "króla polskich kolei," Warszawa, 1983.

Koneczny F., Prawa dziejowe, London, 1982.

Kornat M., "Liberalny internacjonalizm. Jan Bloch, Rosja i sprawy pokoju," in: Jan Bloch, pacyfizm europejski $i$ wyobraźnia Wielkiej Wojny. Studia i rozważania, ed. M. Kornat, Warszawa, 2016, pp. 43-88.

Kuderowicz Z., Polska filozofia pokoju. Historia idei pokoju w kulturze polskiej do 1939 r., Warszawa, 1992.

Lechicka J., Rola dziejowa Stanisława Leszczyńskiego oraz wybór jego pism, Toruń, 1951.

Leszczyński S., Głos wolny wolność ubezpieczajacy, Kraków, 1858.

Libelt K., Karola Libelta rozprawy o odwadze cywilnej, miłości ojczyzny, wychowaniu ludów, Kraków, 1869.

Małecka E., "Konferencja Haska i Jan Bloch przeciwko wielkiej wojnie," Wojsko $i$ Wychowanie, 2000, no. 5, pp. 142-150. 
Martin C., Living the Great Illusion: Sir Norman Angell, 1872-1967, Oxford, 2009.

Miller J.D., Norman Angell and the Futility of War, London, 1986.

Modrzewski A.F., O poprawie Rzeczpospolitej, Warszawa, 1953.

Osmańczyk E., Encyklopedia ONZ i stosunków międzynarodowych, Warszawa, 1982.

Petrycy S., Pisma wybrane, vol. 2, Warszawa, 1959.

Pieczewski A., 'John Bloch's 'The Future of War.' Pacifism Based on Economics," Annales. Etyka w życiu gospodarczym 19, no. 4, pp. 67-80.

Rosa R., Filozofia bezpieczeństwa, Warszawa, 1995.

Rosa R., Wyszczelski L., Wojna i pokój w polskiej myśli społecznej i wojskowej, Warszawa, 1996.

Skrzetuski K., Historia polityczna dla szlachetnej młodzi, Warszawa, 1775.

Staszic S., Pisma filozoficzno-społeczne, Warszawa, 1954.

Stroynowski H., Nauka prawa przyrodzonego, politycznego, ekonomii politycznej $i$ prawa narodów, Vilnius, 1785.

Tatarkiewicz W., Historia filozofii, vol. 1, Warszawa, 2001.

Trentowski B., Stosunek filozofii do cybernetyki, Warszawa, 1974.

Wojciech Bogumit Jastrzębowski (1799-1882), ed. M. Morawska, Warszawa, 2011, http://agad.gov.pl/wp-content/uploads/2016/06/jastrzebowski-internet_1.pdf (1 XI 2019).

Wycech C., Ksiadz Piotr Ściegienny. Zarys programu społecznego i wybór pism, Warszawa, 1953.

Żor A., Figle Historii, Toruń, 2005.

Żor A., "Wokół intelektualnej biografii Jana Blocha," in: Jan Bloch, pacyfizm europejski i wyobraźnia Wielkiej Wojny. Studia i rozważania, ed. M. Kornat, Warszawa, 2016, pp. 15-42.

Andrzej Pieczewski

Economic arguments in the Polish thought on peace. John Bloch's views against the background of the Polish thought on peace

(Summary)

Polish irenology is a rich field of study which has always developed on the basis of the current situation in the country, at the same time reflecting universal, pan-historic values. During the Renaissance, it rarely dealt with economic arguments, but rather focused on the religious and moral aspects of war and sought to develop a distinction between just and unjust wars. In the age of Enlightenment, also known as the era of rationalism, the issue of peace began to be based on more realistic factors rather than just on moral premises. Economic aspects played a very important role, especially in the considerations of Polish physiocrats. Although economic considerations were largely neglected after the subsequent emergence of Romanticism, they made 
a return to the irenological discourse in the era of Positivism, when the issues of war and peace were explained as phenomena determined by social, political, and economic relations. Economic arguments began to play a prominent role. It was claimed that matters of war and peace depend on the technical and economic conditions in which societies live, and the impact of such conditions on politics. In Poland, however, economic aspects had not constituted the main argumentation in favor of peace until the publication of the views of John Bloch. His conclusions were based on a scientific analysis steeped in empiricism. He cited a great amount of statistical data to support his hypotheses, and abandoned moralizing in favor of hard economic argumentation and 'wishful thinking' in favor of scientific analysis. In this sense, he distinguished himself from all previous Polish thinkers and from many international figures involved in the irenological debate.

Andrzej Pieczewski - dr, adiunkt w Katedrze Historii Myśli Ekonomicznej i Historii Gospodarczej Instytutu Ekonomii (na Wydziale Ekonomiczno-Socjologicznym) Uniwersytetu Łódzkiego. Zainteresowania badawcze: ekonomia instytucjonalna, ideowy i praktyczny wkład Polaków w proces integracji europejskiej, myśl ekonomiczna Jana Blocha. Wybrane publikacje: Działalność Józefa Hieronima Retingera na rzecz integracji europejskiej, Torun 2008; Rola $\dot{Z} y d o ́ w ~ w$ rozwoju gospodarczym ziemi łódzkiej. Wybrane zagadnienia, Łódź 2014 (wraz z: J. Skodlarski, R. Matera, K. Lutek, K. Kowalski).

Andrzej Pieczewski - PhD, lecturer at the Department of History of Economic Thought and Economic History of the Faculty of Economics and Sociology, University of Lodz. His scholarly interests include: institutional economy, ideological and practical contribution of Poles to the process of European integration, economic thought of John Bloch. Selected publications: Działalność Józefa Hieronima Retingera na rzecz integracji europejskiej, Torun, 2008; Rola Żydów $w$ rozwoju gospodarczym ziemi tódzkiej. Wybrane zagadnienia, Łódź, 2014 (co-authored with: J. Skodlarski, R. Matera, K. Lutek, K. Kowalski).

E-mail: andrzej.pieczewski@uni.lodz.pl. 